\title{
The Relationship Between Perceived Parental Attitude and Life Satisfaction Among University Students
}

\author{
Nurten Arslan Işik (iD
}

\begin{abstract}
Introduction. The effect of parental attitudes and behaviors in raising their children on the individual's life has been the subject of numerous studies for many years. There is a strong correlation between parental attitudes and the child's ability to be satisfied with life.

The objective of the research was to determine the relationships between perceived parental attitudes (overprotection, rejection, emotional warmth) and life satisfaction among university students. We investigated whether parental attitudes play a role in predicting life satisfaction among university students, and what role they play.

Materials and Methods. The study was conducted from June 2020 to September 2020. Data were collected using Google Forms. Each person consented to anonymously participate in the study and was informed about the objectives of the study being a descriptive one. The population of the study consisted of nursing students enrolled in the Faculty of Health Sciences. For this purpose, 220 students at the age of 20 to 30 years participated in the study. The assessment battery consisted of Student Demographic Form, the Short-Egna Minnen Beträffande Uppfostran (Own Memories of Upbringing), and the Life Satisfaction Scale.

Results. There was a significant negative correlation between maternal rejection and life satisfaction among the students. Male students were more likely to perceive their fathers as being disapproving than female students did. These findings were discussed in line with the studies in the related literature.

Conclusions. High life satisfaction is a variable that protects young people from risk factors. Therefore, a focus should be placed on increasing life satisfaction among students. Parental attitude is an effective factor for life satisfaction among students. For this reason, it can be said that it would be beneficial to inform families about appropriate parental attitudes to increase their children's life satisfaction.
\end{abstract}

\section{Keywords}

Parenting Styles; Life Satisfaction; University Student

Faculty of Health Sciences, Erzincan Binali Yildirim University, Erzincan, Turkey

Corresponding author: nurtenarslanisik1@gmail.com

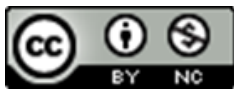

Copyright @Nurten Arslan Işik, 2021

\section{Problem statement and analysis of the latest research}

Life satisfaction involves the cognitive evaluation of one's level of satisfaction in various areas of life and indicates that a person has lived their life well and is satisfied. According to Dem et al. (2016), individuals feel satisfaction when a desire, wish, purpose, or need in their lives are fulfilled [1]. Life satisfaction is a very important factor for individuals to be satisfied with their lives and live a meaningful life. This concept does not refer to a specific aspect of individuals' lives, but to all dimensions [2].

Neugarten (1961), who proposed five criteria to determine life satisfaction among individuals, described people with high life satisfaction as follows:

- Enjoy the daily activities of their lives;

- Believe that their life has meaning by accepting their past experiences and having goals regarding their life;

- Have the belief that they have achieved the goals they have set in their life;

- Have a positive sense of self and feel worthwhile; 
- Have a positive attitude towards life in general [3].

The concept of life satisfaction in young people is influenced by many different factors. Some of them can be listed as the meaning individuals attribute to their lives, the pleasure they derive from their daily lives, the degree to which they achieve their goals, liking their own bodies, having a positive individual identity, socioeconomic status, personal security and social and family relationships [4]. It can be said that one of the most important factors affecting life satisfaction is family relationships [5]. We can see that children who grow up in a family environment, where the relationships between family members are healthy, where there is unconditional love and respect, and where they have the opportunity to develop their talents and self-actualization, feel good and have high life satisfaction. At this point, the parents' attitude towards their children becomes more important.

In the literature, parents' attitudes/behaviors toward their children are classified in different ways. In this study, perceived rejection, emotional warmth, and overprotective parental attitudes, which are three sub-dimensions of the Short-Egna Minnen Beträffande Uppfostran (S-EMBU - Own Memories of Upbringing), were discussed [6]. For this reason, explanations of these perceived parental attitudes are provided below.

\section{Rejection}

Parental disapproval generally refers to behaviors such as disapproval, criticism, arbitrary rebuke, or punishment and indicates a lack of warmth, emotional connection, interest, support, and love [7].

\section{Overprotection}

Parental overprotection has been defined as protective behavior by parents that is excessive, considering the child's developmental level $[8,9]$. Parents with overprotective behavior are characterized by acting like a baby to their children for long periods of time, having excessive contact, being very controlling, having trouble separating from the child, not encouraging independent behavior, being overly controlling, as well as by excessive physical or social communication and excessive anxiety $[10,11]$.

\section{Emotional Warmth}

Emotional warmth has been linked to "the quality of loving relationships between parents and their children and physical and verbal behaviors parents use to express those feelings." Authoritarian parenting behaviors, where parental warmth and control are high, are considered the most effective parenting type $[12,13]$.

There have been several studies that examined the relationship between parental attitudes and life satisfaction. In the study conducted by Coccia et al., a positive significant relationship was found between high life satisfaction, parental tolerance, and low stress levels [14]. In the study conducted by Deniz et al. (2013) with 414 participants, democratic parental attitudes and subjective well-being and life satisfaction were found to be positively significant; there was a significant negative relationship between protective and authoritarian parental attitudes and subjective well-being and life satisfaction [15]. In the study conducted by Ozkan (2014) with 659 participants, it was found that subjective well-being of participants who perceived their parents as democratic and tolerant ones was higher as compared to those who perceived their parents as being neglectful and authoritarian [16]. According to the results of the study carried out by Abubakar et al. (2015) with 500 adolescents, children who experienced inconsistent parenting styles were found to be more likely to have lower life satisfaction [17]. According to the results of the study conducted by Abdi et al. (2015) with 500 university students, it was found that students who perceived their parents as being authoritarian had higher academic achievement and life satisfaction [18]. Xie et al. (2016) in their study involving 718 participants found that among the three parenting styles, authoritarian parenting was most strongly associated with life satisfaction [19]. As a result of the study involving 325 children carried out by Gherasim et al. (2017), children who perceived their mothers as more authoritarian ones wer found to have higher life satisfaction and lower levels of depressive symptoms [20]. According to the study conducted by Pérez-Fuentes et al. (2019) with 742 adolescents, a relationship was found between different dimensions of parenting practices and life satisfaction. Specifically, the higher the score on the variables of affect and communication, promotion of autonomy, humor, and selfdisclosure, the higher the life satisfaction [21]. The results of the study conducted by Diaz (2020) with 2, 373 adolescents revealed that individuals formed emotional bonds, expressed their opinions, feelings, and behaviors without being judged by their parents, there were no conflicts, they were accepted by their parents, and living in a tolerant family environment increased their life satisfaction [22]. Lavrič et al. (2020) carried out a study with 10, 898 participants at the age of 14-29 years and identified a lack of authoritative parental education as the most important factor for lower life satisfaction in young people [23].

According to the results of the study, which examined the relationships between parental attitudes and life satisfaction, individuals who perceived their parents as being accepting, supportive, and tolerant were found to have higher life satisfaction.

The objective of this research was to determine the relationships between perceived parental attitudes and life satisfaction among individuals.

\section{Materials and Methods}

\section{Design, Setting, and Sample}

The research is a descriptive study. The population of the study consisted of nursing students enrolled in the Faculty of Health Sciences. No sampling method was used in the study and the students who volunteered to participate in the study were included in the study (completeness).

Data were collected using Google Forms. Data collection 
instruments used were the Personal Information Form with socio-demographic characteristics, the S-EMBU and the Life Satisfaction Scale (LSS).

\section{Personal Information Form}

The personal information form prepared by the researchers consisted of 14 questions regarding the socio-demographic characteristics and introductory characteristics of the students.

\section{Short-Egna Minnen Beträffande Uppfostran (Own Memories of Upbringing)}

Parents' self-directed behavior as children assesses their perceptions about their forms. It consists of 23 items and is the short form of the original 81 -item version. The S-EMBU includes three subscales: rejection, emotional warmth, and overprotection. The items are scored separately for mothers and fathers on a 4-point Likert-type scale. For this scale, parents answer attitude items separately using a 4-point rating ( $1=$ never, $4=$ most of the time). The scale was adapted into Turkish by Karanc1 et al. (2006). It consists of 7 (2, 6, 9, 12, 14,19 , and 23 for maternal and paternal attitudes) items for the emotional warmth subdimension; $9(3,5,8,10,11,17,18$, 20 , and 22) items for the overprotection subdimension; 7 (1, $4,7,13,15,16$, and 21) items for the rejection subdimension. Of the items in the scale, only the $17^{\text {th }}$ item is reverse coded $(1=4,2=3,3=2,4=1)$ as in the original study and included in the analysis. The same three dimensions emerge in the study. The alpha coefficients for maternal rejection, emotional warmth, and overprotection are $0.80,0.76$, and 0.76 , respectively, and the alpha coefficients for paternal rejection, emotional warmth, and overprotection are $0.82,0.79$, and 0.79 , respectively [24-28].

\section{Life Satisfaction Scale}

The LSS developed by Diener et al. (1985) consists of 5 items and is a 7-point Likert-type scale [4]. The original reliability of the scale is Cronbach's alpha $=0.87$. It was adapted into Turkish by Köker and Yetim (1991) [29]. The LSS is a 5point Likert-type scale consisting of 5 items, with the highest score of 25 and the lowest score of 5 - definitely disagree, disagree, partially agree, agree, absolutely agree. The reliability of the scale was found to be Cronbach's alpha $=0.86$. The validity of the scale is 0.82 . The Cronbach's alpha internal consistency coefficient of the study was found to be 0.86 .

\section{Data Analysis}

The data obtained from the study were assessed by the SPSS 25.0 program. The number, percentage, mean, and standard deviation were used as descriptive statistics. The assumption of data normality was assessed by the KolmogorovSmirnov test. The Mann-Whitney U test was used for data of two groups which did not show normal distribution, and the Kruskal-Wallis $\mathrm{H}$ test was used for more than two groups. Mann-Whitney $U$ analysis was used to determine the origin of the differences among more than two groups. The correlation between the variables was assessed by Spearman's correlation analysis. Significance level was taken as 0.05 .

\section{Results}

\section{Socio-demographic Characteristics of Participants and Their Parents}

The present study was carried out with 220 (154 females and 66 males) participants at the age of 20 to 30 years $(M=22.11$, $\mathrm{SD}=1.51)$. Demographic information is listed in Table 1.

Table 1. Socio-demographic characteristics of participants and their parents.

\begin{tabular}{|c|c|c|}
\hline Variables & Frequency & Percentage $(\%)$ \\
\hline \multicolumn{3}{|l|}{ Gender } \\
\hline Male & 66 & 30 \\
\hline Female & 154 & 70 \\
\hline Age (years) & \multicolumn{2}{|c|}{$20-30$ years $(\mathrm{M}=22.11, \mathrm{SD}=1.51)$} \\
\hline \multicolumn{3}{|c|}{ Marital status of parents } \\
\hline Married & 210 & 95.4 \\
\hline Divorced & 10 & 4.6 \\
\hline \multicolumn{3}{|l|}{ Living style } \\
\hline With parents & 36 & 16.4 \\
\hline \multicolumn{3}{|l|}{ Other (with } \\
\hline $\begin{array}{l}\text { friends, relatives, } \\
\text { or alone) }\end{array}$ & 184 & 83.6 \\
\hline \multicolumn{3}{|l|}{ Place of residence } \\
\hline Village & 34 & 15.5 \\
\hline District & 68 & 30.9 \\
\hline City & 80 & 36.4 \\
\hline Metropolis & 38 & 17.3 \\
\hline \multicolumn{3}{|c|}{ Mother's education } \\
\hline Illiterate & 80 & 36.4 \\
\hline Primary school & 82 & 37.3 \\
\hline $\begin{array}{l}\text { Secondary } \\
\text { school }\end{array}$ & 38 & 17.3 \\
\hline High school & 18 & 8.2 \\
\hline University & 2 & 0.9 \\
\hline \multicolumn{3}{|c|}{ Father's education } \\
\hline Illiterate & 22 & 10 \\
\hline Primary school & 78 & 35.5 \\
\hline $\begin{array}{l}\text { Secondary } \\
\text { school }\end{array}$ & 48 & 21.8 \\
\hline High school & 50 & 22.7 \\
\hline University & 22 & 10 \\
\hline \multicolumn{3}{|l|}{ Health problem } \\
\hline Yes & 28 & 12.7 \\
\hline No & 192 & 87.3 \\
\hline
\end{tabular}

\section{Descriptive Information for the Measures}

In order to examine the descriptive characteristics of the measure means, for both mother and father, standard deviations, the min-max ranges were provided for the S-EMBU with sub- 
scales of emotional warmth, overprotection and rejection, and the LSS (Table 2).

Table 2. Descriptive information for the measures.

\begin{tabular}{lcccc}
\hline Measures & N & Mean & SD & $\begin{array}{c}\text { Min - Max } \\
\text { Values }\end{array}$ \\
\hline $\begin{array}{l}\text { EMBU } \\
\text { Mother }\end{array}$ & & & & \\
$\begin{array}{l}\text { Emotional warmth } \\
\text { Overprotection }\end{array}$ & 220 & 19.52 & 4.04 & $11-28$ \\
$\begin{array}{l}\text { Rejection } \\
\text { Father }\end{array}$ & 220 & 21.90 & 4.24 & $11-31$ \\
$\begin{array}{l}\text { Emotional warmth } \\
\text { Overprotection }\end{array}$ & 220 & 10.62 & 3.43 & $7-22$ \\
Rejection & 220 & 21.14 & 4.45 & $9-31$ \\
LSS & 220 & 10.96 & 4.01 & $7-24$ \\
\hline
\end{tabular}

When we look at the average values, it can be seen that the group mostly perceived overprotection from their mothers. The mean LSS score was found to be $18.26 \pm 5.35$.

\section{Reliability Analysis of Scales}

The S-EMBU scale was examined for subscales of rejection, overprotection and emotional warmth for maternal and paternal responses differently. The results obtained when applying the reliability analysis are shown in Table 3.

Table 3. Reliability analysis of scales.

\begin{tabular}{lcc}
\hline & $\begin{array}{c}\text { Cronbach's } \\
\text { Alfa }\end{array}$ & $\begin{array}{c}\text { Item } \\
\text { number }\end{array}$ \\
\hline S-EMBU & & \\
\hline Mother - Emotional warmth & 0.68 & 7 \\
Mother - Overprotection & 0.55 & 9 \\
Mother - Rejection & 0.64 & 7 \\
\hline Father - Emotional warmth & 0.66 & 7 \\
Father - Overprotection & 0.56 & 9 \\
Father - Rejection & 0.71 & 7 \\
\hline LSS & 0.82 & 5 \\
\hline
\end{tabular}

Regarding parent's gender, marital status, and lifestyle, no significant difference was found in the attitudinal subscales of perceived maternal warmth, overprotection, and rejection of participants (Table 4, $\mathrm{p}>0.05$ ). According to the EMBU subscales, the mean scores for paternal rejection were significantly higher for male participants as compared to female participants $(p<0.01)$. The mean scores of the S-EMBU subdimensions of emotionally warm father in participants whose parents were married were found to be significantly higher as compared to those whose parents were divorced $(\mathrm{p}<0.01)$. No significant difference was found in the emotional warmth, overprotective, and rejection subscales in relation to whether the participants lived with or separated from their family, and the maternal and paternal educational level $(\mathrm{p}>0.05)$.

\section{Correlation Coefficients Between Variables Exam- ined in the Present Study}

In order to investigate the relationships between subscales of the S-EMBU, including emotional warmth, overprotection and rejection for both mother and father, LSS Spearman's correlation analyses were performed.

According to the results of correlation analysis (Table 5), there was a significant negative correlation between the LSS and perceived maternal rejection $(r=-0.195, p<0.01)$. According to the results for perceived maternal parenting styles, maternal emotional warmth revealed positive correlations with maternal overprotection $(\mathrm{r}=0.203, \mathrm{p}<0.01)$, maternal rejection $(\mathrm{r}=0.171, \mathrm{p}<0.01)$ and paternal emotional warmth $(\mathrm{r}=0.722, \mathrm{p}<0.01)$. Secondly, maternal overprotection was positively associated with maternal rejection $(r=0.294$, $\mathrm{p}<0.01)$, paternal emotional warmth $(\mathrm{r}=0.154, \mathrm{p}<0.05)$, paternal overprotection $(\mathrm{r}=0.731, \mathrm{p}<0.05)$ and paternal rejection $(\mathrm{r}=0.153, \mathrm{p}<0.05)$. Finally, maternal rejection was positively correlated with paternal emotional warmth $(\mathrm{r}=$ $0.156, \mathrm{p}<0.01)$, paternal overprotection $(\mathrm{r}=0.200, \mathrm{p}<0.01)$ and paternal rejection $(\mathrm{r}=0.400, \mathrm{p}<0.01)$. According to the results for perceived paternal parenting styles, paternal overprotection was positively correlated with paternal rejection $(\mathrm{r}=0.310, \mathrm{p}<0.01)$ (Table 5).

\section{Discussion}

Numerous studies have demonstrated that family relationships have a significant impact on life satisfaction among young people. Young people with high life satisfaction have been found to have more positive relationships with their parents.

According to our results, no significant difference was found in the attitudinal subscales of perceived maternal emotional warmth, overprotection, and rejection in relation to gender, maternal and paternal education, and lifestyle. In our study, the mean scores of maternal emotional warmth in the S-EMBU subscales of female participants were not significantly different as compared to male participants, while the mean scores of paternal rejection were significantly higher in the EMBU subscales of male participants as compared to female participants. In parallel with our study, Buschgens et al. (2010) reported that male adolescents perceived their parents as more rejecting than girls did [30]. Similarly, in another study, males perceived their fathers as more rejecting than daughters did. In the same study, girls perceived their fathers as emotionally warmer but reported being more cared for by their mothers than boys [31]. According to the results of another study conducted with university students, male students perceived their parents as more rejecting than female students did [32]. Conversely, in another study conducted with adolescents, girls were found to perceive their parents as more disapproving and overprotective than boys did [33-35]. 
Table 4. Differences of demographic variables in perceived parenting styles.

\begin{tabular}{|c|c|c|c|c|c|c|}
\hline \multirow[b]{2}{*}{ Gender } & \multicolumn{2}{|c|}{$\begin{array}{c}\text { M - Emotional warmth } \\
\text { Mean } \pm \text { SD }\end{array}$} & \multicolumn{2}{|c|}{$\begin{array}{l}\text { M - Overprotection } \\
\text { Mean } \pm \text { SD }\end{array}$} & \multicolumn{2}{|c|}{$\begin{array}{l}\text { M - Rejection } \\
\text { Mean } \pm \text { SD }\end{array}$} \\
\hline & & & & & & \\
\hline Male $(n=66)$ & $19.06 \pm 4.23$ & $\mathrm{Z:}-1.14$ & $21.42 \pm 4.38$ & $Z:-1.323$ & $10.63 \pm 3.56$ & $Z:-0.154$ \\
\hline Female $(\mathrm{n}=154)$ & $19.72 \pm 3.96$ & $\mathrm{p}=0.254$ & $22.11 \pm 4.17$ & $\mathrm{p}=0.186$ & $10.62 \pm 3.38$ & $\mathrm{p}=0.877$ \\
\hline \multicolumn{7}{|l|}{ Marital status of parents } \\
\hline Married $(n=210)$ & $19.51 \pm 4.05$ & $Z:-0.275$ & $21.81 \pm 4.27$ & $Z:-1.511$ & $10.56 \pm 3.46$ & $Z:-1.871$ \\
\hline Divorced $(n=10)$ & $19.80 \pm 4.07$ & $p=0.783$ & $23.80 \pm 3.08$ & $\mathrm{p}=0.131$ & $12.00 \pm 2.30$ & $\mathrm{p}=0.061$ \\
\hline \multicolumn{7}{|l|}{ Living style } \\
\hline With parents $(\mathrm{n}=38)$ & $19.78 \pm 3.74$ & $\mathrm{Z}: 1.541$ & $22.00 \pm 4.95$ & Z: 0.680 & $10.42 \pm 2.94$ & $\mathrm{Z}: 0.582$ \\
\hline \multirow[t]{2}{*}{$\begin{array}{l}\text { Other (with friends, relatives, or } \\
\text { alone) }(\mathrm{n}=182)\end{array}$} & $19.47 \pm 4.11$ & $\mathrm{p}=0.215$ & $21.89 \pm 4.09$ & $\mathrm{p}=0.409$ & $10.67 \pm 3.53$ & $\mathrm{p}=0.445$ \\
\hline & \multicolumn{2}{|c|}{$\begin{array}{c}\text { F - Emotional warmth } \\
\text { Mean } \pm \text { SD }\end{array}$} & \multicolumn{2}{|c|}{$\begin{array}{c}\text { F - Overprotection } \\
\text { Mean } \pm \text { SD }\end{array}$} & \multicolumn{2}{|c|}{$\begin{array}{c}\text { F - Rejection } \\
\text { Mean } \pm \text { SD }\end{array}$} \\
\hline \multicolumn{7}{|l|}{ Gender } \\
\hline Male $(n=66)$ & $17.66 \pm 4.20$ & Z: -0.1809 & $20.81 \pm 4.44$ & $Z:-0.723$ & $12.00 \pm 3.81$ & $Z: 3.428$ \\
\hline Female $(\mathrm{n}=154)$ & $18.76 \pm 3.81$ & $\mathrm{p}=0.070$ & $21.28 \pm 4.47$ & $\mathrm{p}=0.469$ & $10.51 \pm 4.02$ & $\mathbf{p}=\mathbf{0 . 0 0 1} * *$ \\
\hline \multicolumn{7}{|l|}{ Marital status of parents } \\
\hline Married $(n=210)$ & $18.69 \pm 3.69$ & $Z:-2.939$ & $21.19 \pm 4.35$ & $Z:-0.112$ & $10.60 \pm 4.06$ & $Z: 0.464$ \\
\hline Divorced $(n=10)$ & $13.00 \pm 5.45$ & $\mathbf{p}=0.003 * *$ & $20.20 \pm 6.51$ & $\mathrm{p}=0.911$ & $11.00 \pm 2.98$ & $p=0.643$ \\
\hline \multicolumn{7}{|l|}{ Living Style } \\
\hline With parents $(\mathrm{n}=38)$ & $18.15 \pm 4.58$ & Z: -0.624 & $21.00 \pm 4.84$ & $\mathrm{Z}:-0.141$ & $10.42 \pm 2.94$ & $\mathrm{Z}: 1.255$ \\
\hline $\begin{array}{l}\text { Other (with friends, relatives, or } \\
\text { alone) }(\mathrm{n}=182)\end{array}$ & $18.49 \pm 3.82$ & $\mathrm{p}=0.533$ & $21.17 \pm 4.38$ & $\mathrm{p}=0.533$ & $10.67 \pm 3.53$ & $\mathrm{p}=0.210$ \\
\hline
\end{tabular}

Table 5. Spearman's correlations between study measures.

\begin{tabular}{lccccccc}
\hline & $(1)$ & $(2)$ & $(3)$ & $(4)$ & $(5)$ & $(6)$ & $(7)$ \\
\hline (1) LSS & 1 & 0.104 & -0.026 & $-\mathbf{0 . 1 9 5}^{* *}$ & 0.008 & -0.106 & -0.135 \\
(2) Mother's emotional warmth & & 1 & $\mathbf{0 . 2 0 3} * *$ & $\mathbf{0 . 1 7 1}^{* *}$ & $\mathbf{0 . 7 2 2}^{* *}$ & 0.031 & -0.018 \\
(3) Mother's overprotection & & & 1 & $\mathbf{0 . 2 9 4}^{* *}$ & $\mathbf{0 . 1 5 4}^{*}$ & $\mathbf{0 . 7 3 1}^{* *}$ & $\mathbf{0 . 1 5 3}^{*}$ \\
(4) Mother's rejection & & & & 1 & $\mathbf{0 . 1 5 6}^{*}$ & $\mathbf{0 . 2 0 0}^{* *}$ & $\mathbf{0 . 4 0 0}^{* *}$ \\
(5) Father's emotional warmth & & & & & 1 & 0.115 & -0.110 \\
(6) Father's overprotection & & & & & & 1 & $\mathbf{0 . 3 1 0}^{* *}$ \\
(7) Father's rejection & & & & & & & 1 \\
\hline Notes: $*$ - p $<0.05, * *-p<0.01$ & & & & & & &
\end{tabular}

According to the literature, fathers adopt a distant and disapproving attitude in the relationships with their sons due to the influence of gender roles. The results of our study are consistent with the literature.

There was no statistically significant difference in parental attitude depending on the level of education. Several studies have shown that parental education had an impact on maternal and paternal attitudes. Studies have shown that students perceived parental attitudes as democratic when maternal and paternal education levels increased, and they perceived parental attitudes as more authoritarian when their education levels decreased [36-38]. Duncan et al. (1994) found that there was a positive relationship between parents' educational level and parental warmth. However, inadequate parental education was reported to have a negative impact on the quality of child rearing $[35,38,39]$. For example, a study conducted by McCarthy et al. (2016) reported that mothers with low levels of education used more physical and psychological punishment on their children [40]. The inconsistency of the study findings with the literature can be explained by the fact that parental educational level in the present sample was primary school.

No significant difference was found in the subscales of emotional warmth, overprotection and rejection attitude in relation to living with family, or separation of the participants. The fact that the results of the present study are not consistent with the literature is probably due to the fact that only a small proportion of the sample lived with their families. A study conducted by Demirsu (2018) found that the mean score of 
emotional warmth subdimensions was significantly higher in students living with their family as compared to those not living with family [41]. The hypothesis is that individuals living with their family receive more emotional closeness and support from their parents than those who do not live with their family. The mean score of perceived emotional warmth from the father was significantly higher among participants whose parents were married as compared to participants whose parents were divorced. However, the interpretation of this result may not be reliable as the majority of parents in the current sample were married.

According to the results of correlation analysis, a significant negative relationship was found between the LSS and perceived maternal rejection. Individuals' life satisfaction decreased when the level of mother's rejection increased. In other words, life satisfaction decreased when the level of democratic attitude decreased [42]. Family relationships are based on love, respect and trust; the healthiest parental attitude is one that values, trusts and respects the child, where the child is accepted, the child is involved in the rules and decisions. Studies have shown that the better the relationships with the mother, the more satisfied people are with their lives. In other words, it has been observed that people who are in healthy and positive communication with their mother have higher life satisfaction [42-44].

\section{Conclusions}

The results of this study showed that the parenting model does indeed affect students' life satisfaction. Warmer, less rejecting, and less punitive parents raise children who are happier, more emotionally stable, more hopeful about the future, and have higher life satisfaction, but future studies will accept more conclusive evidence.

\section{Limitations}

The present study has methodological limitations. The study was conducted with a total number of 235 participants. However, due to missing items and outliers, the analyses were conducted with 220 participants. Although the sample size was sufficient for statistical analyses, further studies can be conducted with a larger sample size. The possibility of similar response bias exists with the S-EMBU scale, which measures perceived parenting style in childhood. Additionally, as participants transition to adulthood with increasing family conflict and desire for independence, they may have negative attitudes toward parents. Therefore, longitudinal studies are suggested to observe the long-term effects of early experiences.

Despite the summary limitations, this study aimed to understand the dynamic structure of early experiences and their inevitable effects on functioning in adulthood. Future research would benefit from expanding the study to a large population.

\section{Ethical Statement}

The study was conducted between June 2020 - September 2020 with the consent of the Ethics Committee of the Faculty of Health Sciences.

\section{Informed Consent}

Each individual consented to anonymous participation in the study and was informed of its objectives.

\section{Conflict of Interest}

The author declares that no conflicts exist.

\section{Financial Disclosure}

The author declared no financial support.

\section{References}

[1] Dem U, Swartz M, Mirecki I, Barak Y. Physicians' life satisfaction in Bhutan: a nationwide survey. Open Journal of Psychiatry [Internet]. 2016;06(01):119-124. Available from: https://doi.org/10.4236/ojpsych.2016.61014

[2] Yildirim T. Examining the relationship between selfesteem and perceived social support and life satisfaction among university students [Master's Thesis]. Istanbul: Haliç University.

[3] Ümmet D. Exploring altruism behavior in university students in the context of transactional analysis ego states and life satisfaction [Doctoral Thesis]. Istanbul: Marmara University, Institute of Educational Sciences.

[4] Yılmaz H, Arslan C. Subjective well-being, positive and negative affect in Turkish university students. Online Journal of Counseling \& Education. 2013;2(2):1-8.

[5] Cenkseven-Önder F. The influence of decision-making styles on early adolescents' life satisfaction. Social Behavior and Personality: an international journal [Internet]. 2012;40(9):1523-1536. Available from: https://doi.org/10.2224/sbp.2012.40.9.1523

[6] Arrindell WA, Sanavio E, Aguilar G, Sica C, Hatzichristou C, Eisemann M, et al. The development of a short form of the EMBU 1Swedish acronym for Egna Minnen Beträffande Uppfostran ("My memories of upbringing"). 1: Its appraisal with students in Greece, Guatemala, Hungary and Italy. Personality and Individual Differences [Internet]. 1999;27(4):613-628. Available from: https://doi.org/10.1016/S0191-8869(98)00192-5

[7] Rohner RP, Khaleque A. Testing central postulates of parental acceptance-rejection theory (PARTheory): a meta-analysis of cross-cultural studies. Journal of Family Theory \& Review [Internet]. 2010;2(1):73-87. 
Available from: https://doi.org/10.1111/j.17562589.2010.00040.x

[8] Holmbeck GN, Johnson SZ, Wills KE, McKernon W, Rose B, Erklin S, et al. Observed and perceived parental overprotection in relation to psychosocial adjustment in preadolescents with a physical disability: the mediational role of behavioral autonomy. Journal of Consulting and Clinical Psychology [Internet]. 2002;70(1):96-110. Available from: https://doi.org/10.1037//0022-006X.70.1.96

[9] Hemm C, Dagnan D, Meyer TD. Social anxiety and parental overprotection in young adults with and without intellectual disabilities. Journal of Applied Research in Intellectual Disabilities [Internet]. 2017;31(3):360-368. Available from: https://doi.org/10.1111/jar.12413

[10] Kane EJ, Braunstein K, Ollendick TH, Muris P. Relations of anxiety sensitivity, control beliefs, and maternal over-control to fears in clinic-referred children with specific phobia. Journal of Child and Family Studies [Internet]. 2014;24(7):2127-2134. Available from: https://doi.org/10.1007/s10826-014-0014-5

[11] Yap MBH, Pilkington PD, Ryan SM, Jorm AF. Parental factors associated with depression and anxiety in young people: a systematic review and meta-analysis. Journal of Affective Disorders [Internet]. 2014;156:8-23. Available from: https://doi.org/10.1016/j.jad.2013.11.007

[12] Wu L, Zhang D, Cheng G, Hu T, Rost DH. Parental emotional warmth and psychological Suzhi as mediators between socioeconomic status and problem behaviours in Chinese children. Children and Youth Services Review [Internet]. 2015;59:132-138. Available from: https://doi.org/10.1016/j.childyouth.2015.09.019

[13] Becoña E, Calafat A, Fernández-Hermida JR, Juan M, Sumnall H, Mendes F, Gabrhelík R. Parental permissiveness, control, and affect and drug use among adolescents. Psicothema. 2013;25(3):292-298. Available from: https://doi.org/10.7334/psicothema2012.294

[14] Coccia C, Darling CA, Rehm M, Cui M, Sathe SK. Adolescent health, stress and life satisfaction: the paradox of indulgent parenting. Stress and Health [Internet]. 2011;28(3):211-221. Available from: https://doi.org/10.1002/smi.1426

[15] Deniz ME, Karakuş O, Traş Z, Eldeleklioğlu J, Ozyeşil Z, Hamarta E. Parental attitude perceived by university students as predictors of subjective well-being and life satisfaction. Psychology [Internet]. 2013;04(03):169-173. Available from: https://doi.org/10.4236/psych.2013.43025

[16] Sari T, Ozkan I. An investigation of the relationship between adolescents' subjective well-being and perceived parental attitudes. Dusunen Adam:
The Journal of Psychiatry and Neurological Sciences [Internet]. 2016;2(29):155-162. Available from: https://doi.org/10.5350/DAJPN2016290207

[17] Abubakar A, Van de Vijver FJR, Suryani AO, Handayani P, Pandia WS. PPerceptions of parenting styles and their associations with mental health and life satisfaction among urban Indonesian adolescents. Journal of Child and Family Studies [Internet]. 2014;24(9):2680-2692. Available from: https://doi.org/10.1007/s10826-0140070-x

[18] Abdi M, Yasavoli HM, Yasavoli MM. Assessment of structural model to explain life satisfaction and academic achievement based on parenting styles. Procedia - Social and Behavioral Sciences [Internet]. 2015;182:668-672. Available from: https://doi.org/10.1016/j.sbspro.2015.04.806

[19] Xie Q, Fan W, Wong P, Cheung FM. Personality and parenting style as predictors of life satisfaction among Chinese secondary students. The Asia-Pacific Education Researcher [Internet]. 2015;25(3):423-432. Available from: https://doi.org/10.1007/s40299-015-0271-0

[20] Gherasim LR, Brumariu LE, Alim CL. Parenting style and children's life satisfaction and depressive symptoms: preliminary findings from Romania, France, and Russia. Journal of Happiness Studies [Internet]. 2016;18(4):1013-1028. Available from: https://doi.org/10.1007/s10902-016-9754-9

[21] Pérez-Fuentes M del C, Molero Jurado M del M, Gázquez Linares JJ, Oropesa Ruiz NF, Simón Márquez M del M, Saracostti M. Parenting practices, life satisfaction, and the role of self-esteem in adolescents. International Journal of Environmental Research and Public Health [Internet]. 2019;16(20):4045. Available from: https://doi.org/10.3390/ijerph16204045

[22] Povedano-Diaz A, Muñiz-Rivas M, Vera-Perea M. Adolescents' life satisfaction: the role of classroom, family, self-concept and gender. International Journal of Environmental Research and Public Health [Internet]. 2019;17(1):19. Available from: https://doi.org/10.3390/ijerph17010019

[23] Lavrič M, Naterer A. The power of authoritative parenting: a cross-national study of effects of exposure to different parenting styles on life satisfaction. Children and Youth Services Review [Internet]. 2020;116:105274. Available from: https://doi.org/10.1016/j.childyouth.2020.105274

[24] Diener E, Emmons RA, Larsen RJ, Griffin S. The satisfaction with life scale. Journal of Personality Assessment [Internet]. 1985;49(1):71-75. Available from: https://doi.org/10.1207/s15327752jpa4901_13 
[25] Köker, S. Comparison of normal and problematic adolescents' level of life satisfaction [Master Thesis]. Ankara: Institute of Social Science, Ankara University; 1991.

[26] Yetİm Ü. Life satisfaction: a study based on the organization of personal projects. Social Indicators Research [Internet]. 1993;29(3):277-289. Available from: https://doi.org/10.1007/BF01079516

[27] Buschgens CJM, van Aken MAG, Swinkels SHN, Ormel J, Verhulst FC, Buitelaar JK. Externalizing behaviors in preadolescents: familial risk to externalizing behaviors and perceived parenting styles. European Child \& Adolescent Psychiatry [Internet]. 2009;19(7):567-575. Available from: https://doi.org/10.1007/s00787-009-0086-8

[28] Someya T, Uehara T, Kadowaki M, Sakado K, Reist C, Tang SW, et al. Factor analysis of the EMBU scale in a large sample of Japanese volunteers. Acta Psychiatrica Scandinavica [Internet]. 1999;100(4):252-257. Available from: https://doi.org/10.1111/j.16000447.1999.tb10858.x

[29] Kula H, Ayhan C, Soyer F. The relationship between smartphone addiction and life satisfaction: faculty of sport sciences students. International Journal of Psychology and Educational Studies [Internet]. 2020;7(1):86-95. Available from: https://doi.org/10.17220/ijpes.2020.01.008

[30] Buschgens CJM, van Aken MAG, Swinkels SHN, Ormel J, Verhulst FC, Buitelaar JK. Externalizing behaviors in preadolescents: familial risk to externalizing behaviors and perceived parenting styles. European Child \& Adolescent Psychiatry [Internet]. 2009;19(7):567-575. Available from: https://doi.org/10.1007/s00787-009-0086-8

[31] Berkien M, Louwerse A, Verhulst F, van der Ende J. Children's perceptions of dissimilarity in parenting styles are associated with internalizing and externalizing behavior. European Child \& Adolescent Psychiatry [Internet]. 2012;21(2):79-85. Available from: https://doi.org/10.1007/s00787-011-0234-9

[32] Dural G, Yalcin I. Investigation of relationship between parental acceptance and psychological adjustment among university students. Dusunen Adam: The Journal of Psychiatry and Neurological Sciences [Internet]. 2014;27:221-232. Available from: https://doi.org/10.5350/DAJPN2014270305

[33] Nishikawa S, Sundbom E, Hägglöf B. Influence of perceived parental rearing on adolescent self-concept and internalizing and externalizing problems in Japan. Journal of Child and Family Studies [Internet]. 2009;19(1):57-66. Available from: https://doi.org/10.1007/s10826-0099281-y
[34] Maskur S, Faisal M, Said K. Parents's Over Protective Attitudes Towards Social Development of Children. European Journal of Molecular \& Clinical Medicine. 2020;7(6):571-578. Available from: https://ejmcm.com/article_2798.html

[35] Kochanska G, Aksan N, Penney SJ, Boldt LJ. Parental personality as an inner resource that moderates the impact of ecological adversity on parenting. Journal of Personality and Social Psychology [Internet]. 2007;92(1):136-150. Available from: https://doi.org/10.1037/0022-3514.92.1.136

[36] Bornstein MH, Zlotnik D. Parenting styles and their effects. In: Haith MM, Benson JB. Encyclopedia of Infant and Early Childhood Development [Internet]. Academic Press; 2020. 470-480. Available from: https://doi.org/10.1016/B978-0-12-809324-5.23611-0

[37] Aydoğdu F, Dilekmen M. Evaluation of parental attitudes in terms of various variables. Journal of Bayburt Education Faculty. 2016;11(2). Available from: https://dergipark.org.tr/en/pub/befdergi/issue/28762/307860

[38] Alpoğuz D, Şahin A. The effect of democratic or authoritarian perceived parent attitudes on primary school students' academic success at Turkish language. Ana Dili Eğitimi Dergisi [Internet]. 2014;2(3):53-67. Available from: https://doi.org/10.16916/aded.92531

[39] Duncan GJ, Brooks-Gunn J, Klebanov PK. Economic deprivation and early childhood development. Child Development [Internet]. 1994;65(2):296. Available from: https://doi.org/10.2307/1131385

[40] McCarthy RJ, Crouch JL, Basham AR, Milner JS, Skowronski JJ. Validating the voodoo doll task as a proxy for aggressive parenting behavior. Psychology of Violence [Internet]. 2016;6(1):135-144. Available from: https://doi.org/10.1037/a0038456

[41] Demirsu Ö. The mediating roles of resilience and anxiety sensitivity on the relationship between perceived parental attitudes and trait anxiety [Master's thesis]. Istanbul: Işık University; 2018.

[42] Cheng HG, Anthony JC, Huang Y. Harsh physical punishment as a specific childhood adversity linked to adult drinking consequences: evidence from China. Addiction [Internet]. 2010;105(12):2097-2105. Available from: https://doi.org/10.1111/j.1360-0443.2010.03079.x

[43] Shek DTL, Chan LK. Hong Kong Chinese parents' perceptions of the ideal child. The Journal of Psychology [Internet]. 1999;133(3):291-302. Available from: https://doi.org/10.1080/00223989909599742 
[44] Lampropoulou A. The role of the family in adolescents' subjective well-being. Psychiatriki [Internet]. 2018;29(2):172-182. Available from: https://doi.org/10.22365/jpsych.2018.292.172
Received: 2021-03-12

Revised: 2021-04-12

Accepted: 2021-04-28 